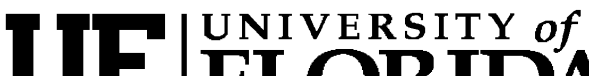 FLORIDA \\ IFAS Extension
}

\section{Flowering Vines for Florida ${ }^{1}$}

\section{Sydney Park Brown and Gary W. Knox ${ }^{2}$}

Many flowering vines thrive in Florida's mild climate. By carefully choosing among this diverse and wonderful group of plants, you can have a vine blooming in your landscape almost every month of the year.

Vines can function in the landscape in many ways. When grown on arbors, they provide lovely "doorways" to our homes or provide transition points from one area of the landscape to another.

Undesirable trees, posts, and poles can be transformed using vines to alter their form, texture and color. Vines can be used to soften and add interest to fences, walls and other hard spaces.

A deciduous vine grown over a patio provides a cool retreat in summer and a sunny outdoor living area in winter. Muscadine and bunch grapes are deciduous vines that fulfill that role and produce abundant fruit. For more information on selecting and growing grapes in Florida, go to http://edis.ifas.ufl.edu/AG208 or contact your county extension office for a copy.

Vines can be used as living walls that provide privacy and/or screen unsightly views. Narrow plant beds are the perfect spot to "vertically garden" with a vine and, finally, vines attract wildlife. They provide

CIRCULAR 860

\section{CIRCULAR 860}


vines include Passion Vine and Cross Fine that climb by means of tendrils that curl around supports in response to friction. These can be used to cover lattice, wire mesh, or other supports that spread horizonatally. Examples of vines that climb by tendrils include painted trumpet (Clytostoma callistegioides) and passion vines (Passiflora species). Cliinging vines are often used to cover solid upright surfaces such as trees, fences, or walls. Vines grown on wooden walls or fences may prevent the wood surface from drying and increase the chance of decay.

Twining vines climb by encircling upright vertical supports. They are often used on poles, vertical wires, or lattice structures. Most of these vines will spiral in only one direction characteristic of the species. If made to spiral in the opposite direction, most will not cooperate and the vine may be damaged. Twining vines include mandevilla (Mandevilla splendens), Confederate jasmine (Trachelospermum jasminoides), and allamanda (Allamanda cathartica).

Sprawling or clamboring vines are basically shrubs that produce long runners, but have no means of attaching themselves to a support. This type of vine needs to be manually wound around a support or braced up in some way. With age, they usually become woody and self-supporting. Bougainvillea is an example of a sprawling vine.

\section{The Planting Site}

As with all plants, the "right plant/right place" rule applies. As you read through Table 1, note which area(s) of the state (north, central or south) each vine is adapted to. Vines grown in the cooler northern areas of Florida may not be adapted to warmer regions. Conversely, many tropical or subtropical vines grown in south Florida will not survive the winters of north Florida. Others are killed to the ground by frost or freeze, but sprout back from the roots the following spring.

Although Florida is typically divided into three regions (north, central, and south), the limits of each region for a given plant cannot be exactly defined.
Local conditions such as elevation, bodies of water, proximity to the coast, and other factors influence temperature. Yearly fluctuations in temperature also complicate determinations.

Choose a vine according to the "function" it will play in your landscape (i.e., screening, softening, color, hummingbird attractor, etc.). Consider planting one or more vines together so that when one finishes blooming, another begins, creating a tapestry of foliage and flowers.

Consider how you will support the vine. Many vines, such as Cross Vine and Trumpet Creeper, will grow as tall as their support will allow. Foliage and flowers often are sparse near the ground and greatest near the uppermost parts of the plants. Flowering can be concentrated at any particular height by providing a "stopping point," or limiting the vertical height of a trellis to the height at which you want the most flowers.

A trellis or other support should be placed several inches away from walls. Such placement allows air movement between wall and vine, reducing humidity and possible mold and mildew growth on surfaces. Vines should be kept off the roof to avoid damage to shingles. Vines can also damage or separate siding if grown on or too close to siding-covered buildings.

Where a plant is located in a landscape will also influence how well it will tolerate cold temperatures. Tender species of vines can be planted on the south and east sides of buildings where they are more protected from cold northwestern winds. Vines planted beside buildings, or under overhangs or trees, get more protection from cold than the same vines planted in exposed locations. Plants in locations that are shaded early in the morning may also suffer less cold damage.

Site characteristics such as amount of sun or shade, salt spray, water drainage and soil type also help determine the type of vine that can be grown and its placement within the landscape.

The amount of sunlight required by vines varies, but most vines grow and flower best in full sunlight to partial shade. 
The tolerance of vines to salt water and salt spray is of particular concern to home gardeners living on Florida's coast. Vines can be selected that are adapted to soils and exposures of coastal areas.

Poor soil drainage causes the roots of some vines to decay while others are adapted to wet areas. However, even tolerant species are normally nursery-produced in well-drained potting soils and may not withstand the transition to a wet site. The best solution is to correct the drainage problem if possible or to plant the vine on a mound (see below).

Like most plants, vines grow best in a slightly acid ( $\mathrm{pH}$ 5.5-6.5), loose, well-drained soil. When conditions differ from this, select vines which are adapted rather than amending or changing soil conditions to suit a particular type of vine.

\section{Selecting Vines}

As with all plants, the "right plant/right place" rule applies. As you read through Table 1, note which area(s) of the state (north, central or south) each vine is adapted to. Vines grown in the cooler northern areas of Florida may not be adapted to warmer regions. Conversely, many tropical or subtropical vines grown in south Florida will not survive the winters of north Florida. Others are killed to the ground by frost or freeze, but sprout back from the roots the following spring.

Although Florida is typically divided into three regions (north, central, and south), the limits of each region for a given plant cannot be exactly defined. Local conditions such as elevation, bodies of water, proximity to the coast, and other factors influence temperature. Yearly fluctuations in temperature also complicate determinations.

Choose a vine according to the "function" it will play in your landscape (i.e., screening, softening, color, hummingbird attractor, etc.). Consider planting one or more vines together so that when one finishes blooming, another begins, creating a tapestry of foliage and flowers.

Consider how you will support the vine. Many vines, such as Cross Vine and Trumpet Creeper, will grow as tall as their support will allow. Foliage and flowers often are sparse near the ground and greatest near the uppermost parts of the plants. Flowering can be concentrated at any particular height by providing a "stopping point," or limiting the vertical height of a trellis to the height at which you want the most flowers.

A trellis or other support should be placed several inches away from walls. Such placement allows air movement between wall and vine, reducing humidity and possible mold and mildew growth on surfaces. Vines should be kept off the roof to avoid damage to shingles. Vines can also damage or separate siding if grown on or too close to siding-covered buildings.

This publication emphasizes flowering vines. Table 2 provides a list of vines grown for their foliage and Table 3 provides a brief list of vines that grow as seasonal annuals.

\section{Planting and Care}

\section{Planting}

Vines can be planted throughout the year in Florida. In north and central Florida, fall and winter planting of cold hardy vines is ideal because plants have time to develop new roots and become established before they resume top growth in the spring. In southern Florida, temperatures are warm enough for year-round planting and growth. However, planting from June through September takes advantage of the rainy season and reduces the amount of irrigation needed to establish plants.

Vines are planted in the same manner as other plants. The planting hole should be dug two to three times the diameter of the root ball and as deep as the root ball is tall. In cases where the soil is hard, compacted or poorly drained, it may be advisable to dig the planting hole half as deep. Then mound the soil to cover the sides of the root ball. A plant installed in this manner may require more frequent irrigation during dry periods, but it is not likely to suffer from subsurface drainage problems.

Water the vine well while it is still in the pot, then carefully remove it from the container. Gently place the plant straight in the hole and be sure the top 
of the root ball is no deeper than the existing soil surface. Fill the hole with the removed native soil. Research has shown that backfilling with organic matter or other amendments is not necessary. Gently firm the soil with your hands; do not pack it with your feet. Water thoroughly. Use the extra backfill soil to construct a saucer-like basin over the root ball. This will help hold water until it drains down to the plant's roots.

\section{Mulching}

Vines should be mulched with 2 to 3 -inches of organic or inorganic material. Mulches insulate the soil and roots, conserve moisture, help control weeds, add organic matter to the soil and improve the appearance of the landscape.

Recommended organic mulches include leaves, pine needles, bark and wood chips. Inorganic materials like gravel and stone can also be used. Avoid using black plastic around plants which will act as a barrier to water and gas exchange. Woven plastic fabric or other types of porous ground cloth can be used to help stabilize the soil, reduce weed penetration and conserve moisture. These materials should be covered with a mulch to prevent their degradation by sunlight and to increase the landscape's aesthetic quality.

Keep a one- to three-inch area around the stems of plants free of mulch to decrease the chance of stem rot.

\section{Watering}

The success or failure of a planting often depends on whether the plants receive adequate moisture. Vines require months to extend roots into the surrounding soil; therefore, they should be watered frequently until they are well established. Start with daily watering for a week or two, then decrease the frequency to two or three times a week. Gradually reduce watering until the plant appears to be capable of surviving on automatic irrigation or rain alone. Time of year, location in the state and the landscape, as well as rainfall amounts will influence how frequently vines need water.

\section{Fertilization}

Establish a newly planted vine by fertilizing two to three times in the first year or two. One application is normally scheduled around February (south Florida) or March (central and north Florida) and another September (north) or October (central and south). The third application can be made during the summer if needed. If the foliage is green and the plant is flowering well, fertilization can be postponed or eliminated.

The amount of fertilizer to apply will depend on the age and size of the plant. Keep in mind that the roots of most established plants, including vines, extend two to three times beyond the plant. Fertilization may be justified when faster growth is desired or when plants exhibit nutrient deficiencies. Phosphorus content of the fertilizer should be $0-2 \%$ $\mathrm{P} 2 \mathrm{O5}$. Historically, the ratio of nitrogen $(\mathrm{N})$ to potassium (K2O) for landscape plants has been in the range of 1:1 to 2:1. An example of a granular landscape fertilizer which fits these criteria is 15-0-15 or something similar. Due to the prevalence of magnesium $(\mathrm{Mg})$ deficiency on certain landscape plants in many parts of the state, up to 2.5 pounds $\mathrm{Mg} / 1000 \mathrm{ft} /$ year may be applied to address this problem. Micronutrients can be applied at specified rates and timing to achieve fertilization objectives.

Well-established vines often don't require fertilizer. Over-fertilizing induces excessive, aggressive growth and increases pruning requirements.

\section{Pruning}

Vines, by nature, are vigorous plants which will require occasional pruning to keep them in bounds and on their supports. Vines growing up walls should be kept off the roof to avoid damaging shingles.

Flowering vines should be pruned shortly after the blooming period. Later pruning may damage next year's buds and earlier pruning could remove the current season's flowers.

Your county Extension office can provide more information: http://solutionsforyourlife.ufl.edu/map/ 


\section{References:}

Some of the information in this fact sheet was previously published as: Vines for Florida by Robert J. Black, retired Professor Emeritus, Environmental Horticulture Department, University of Florida/IFAS, Gainesville. 


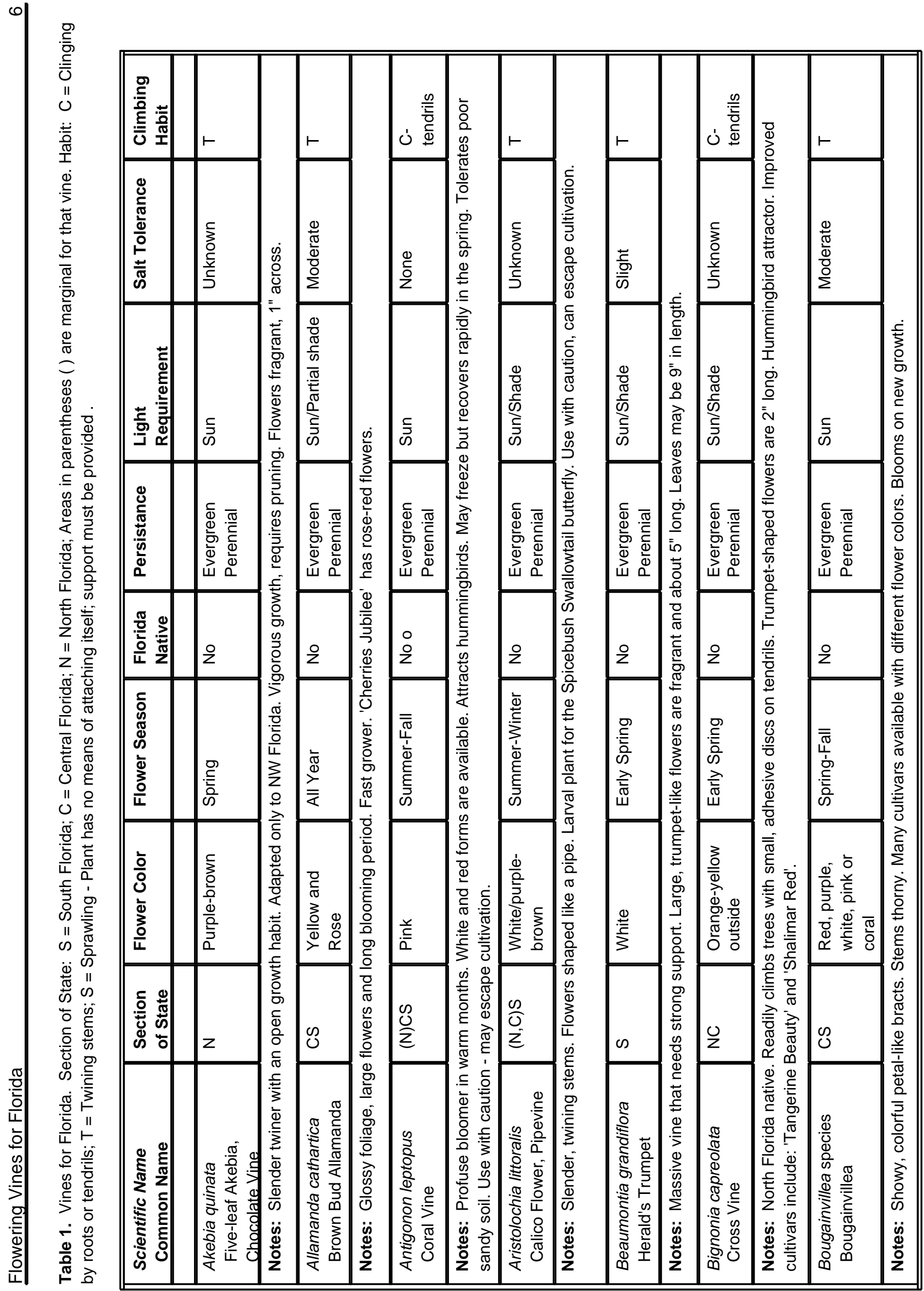




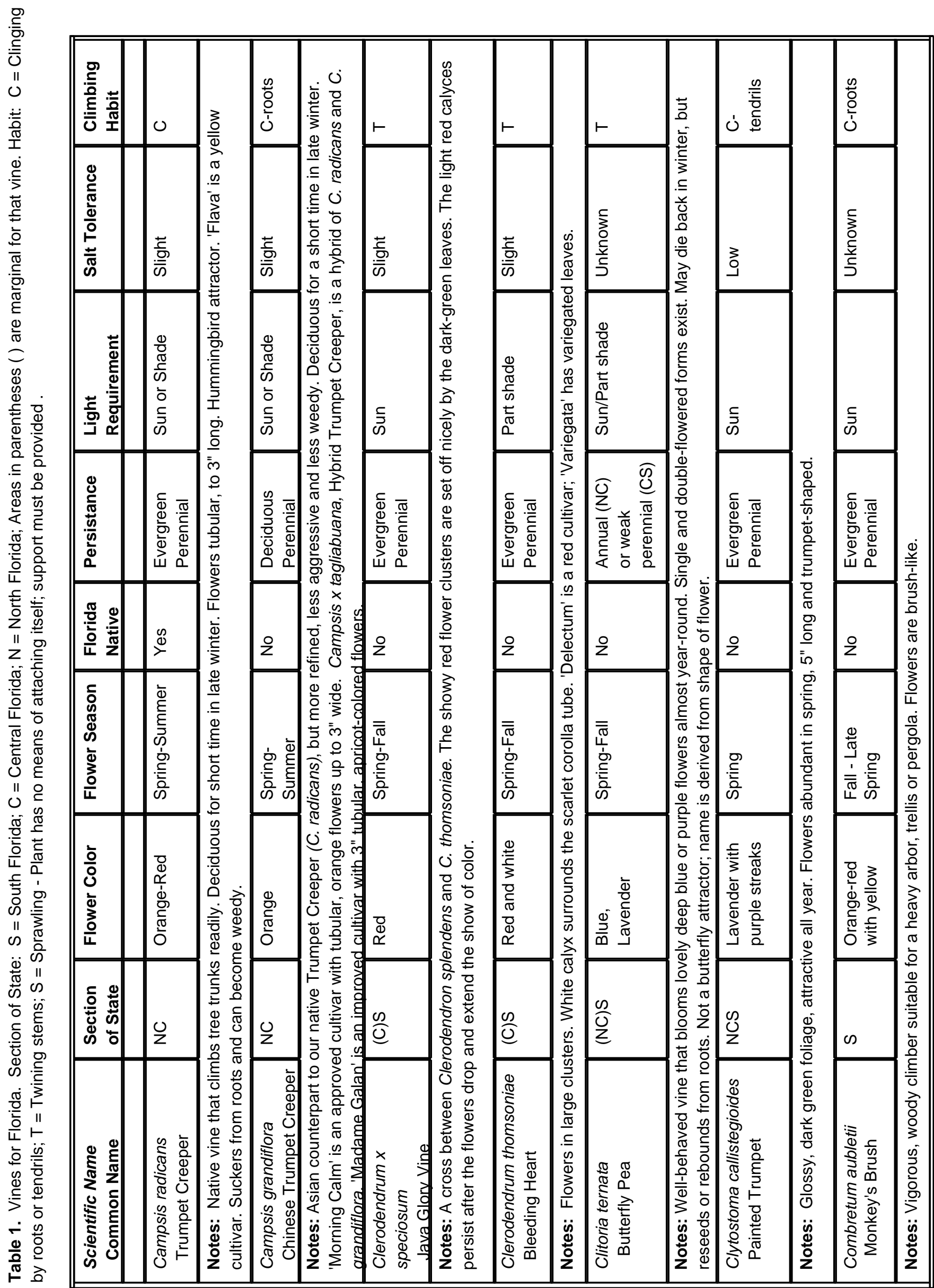




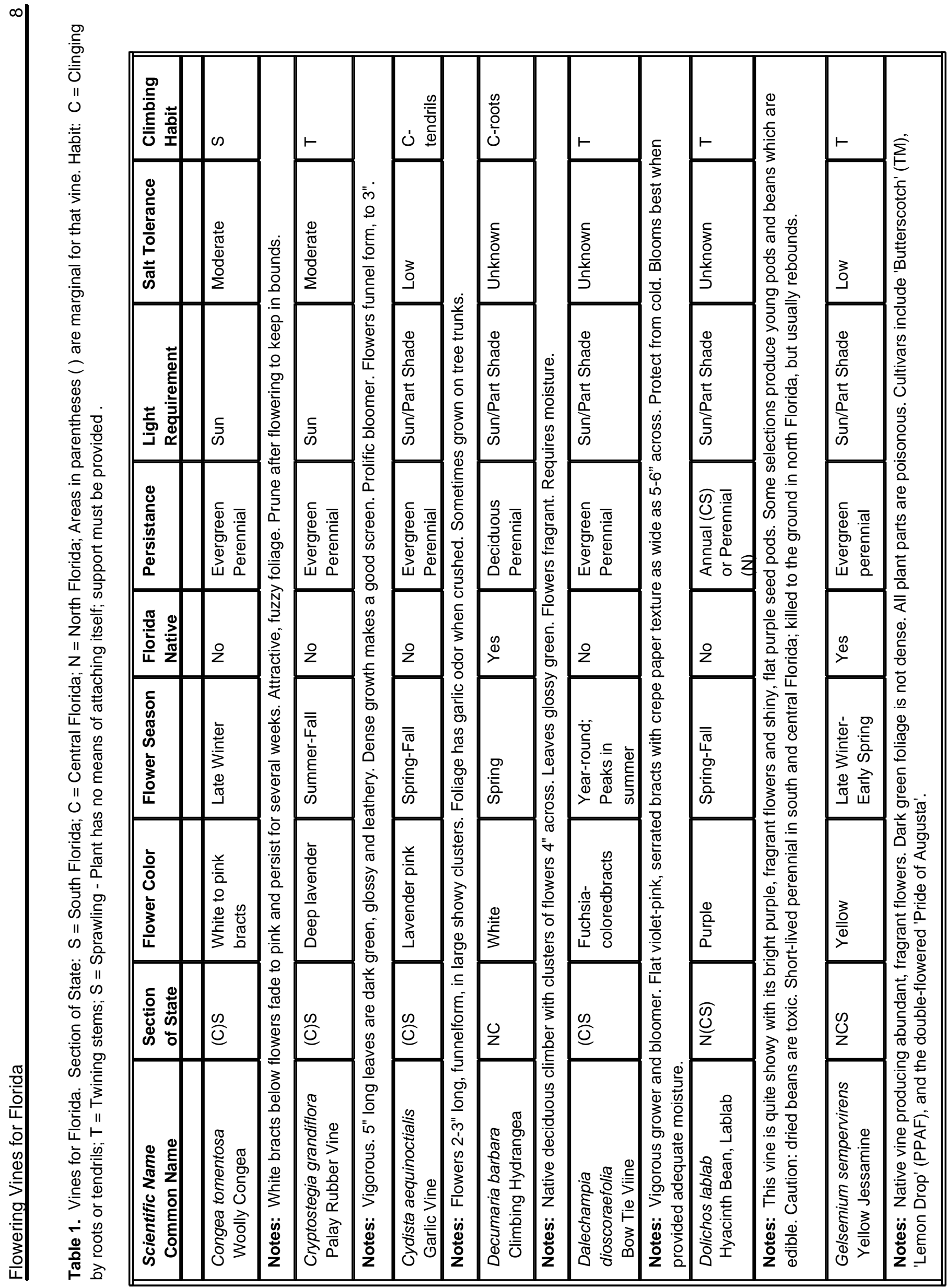




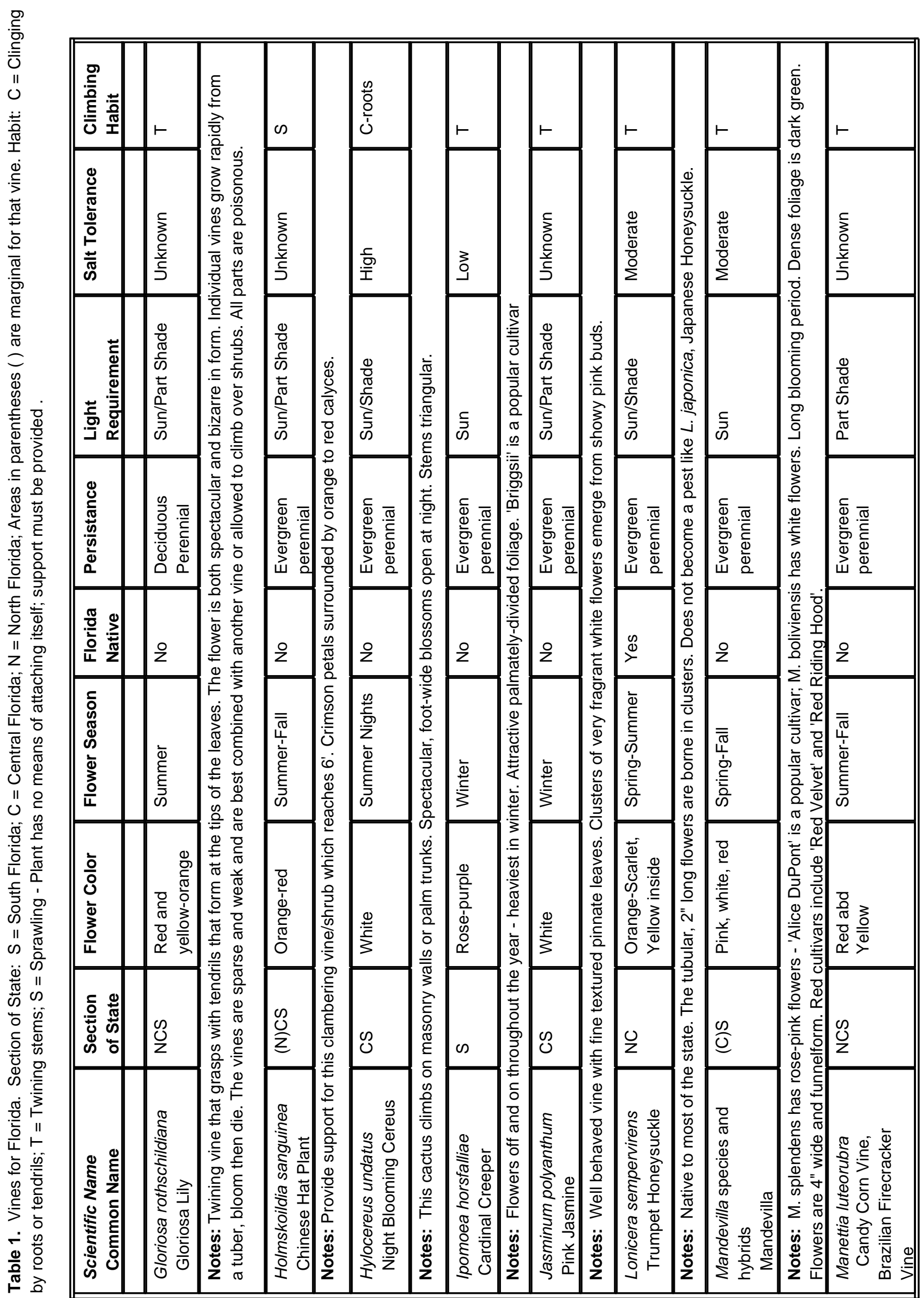




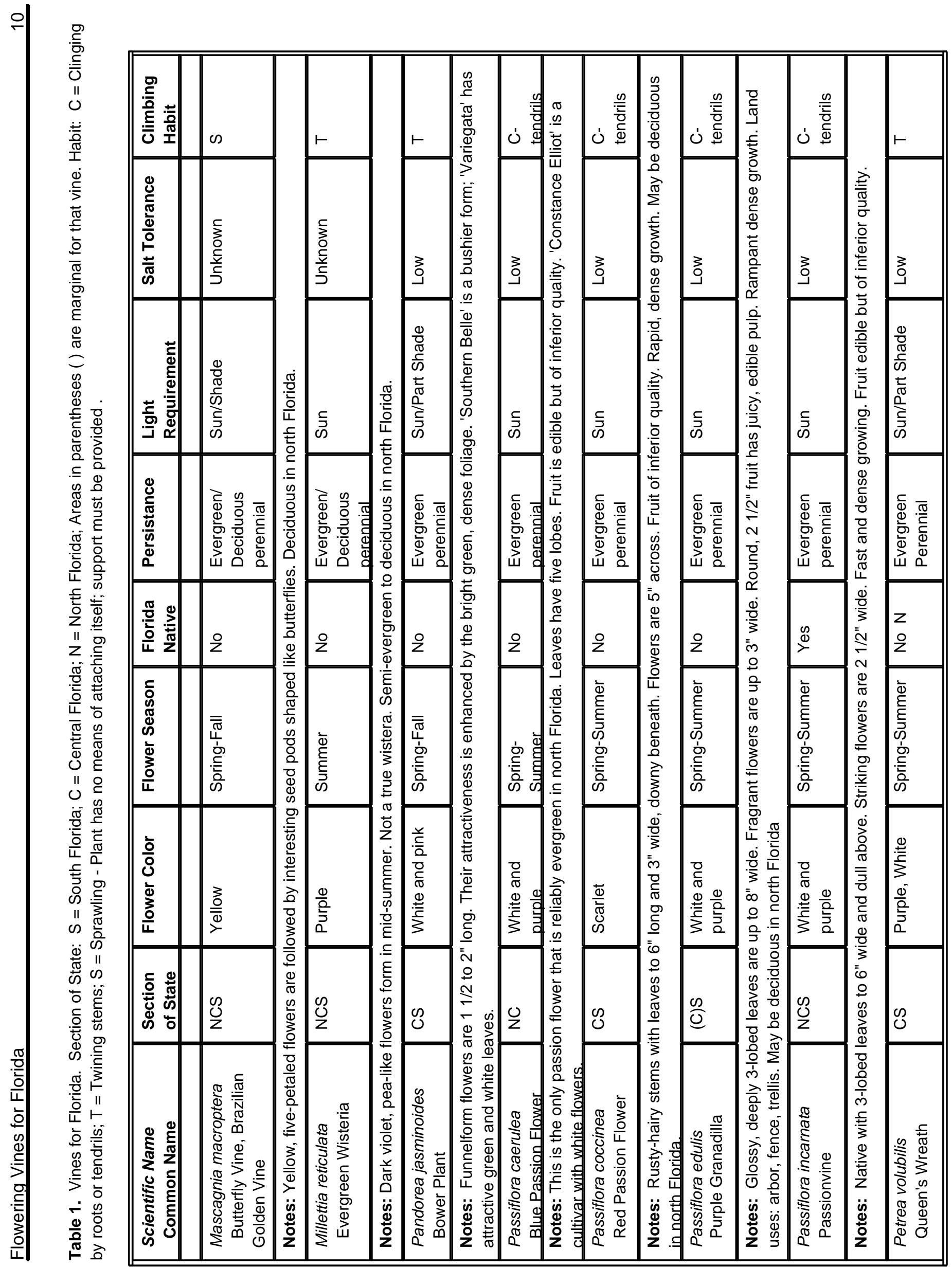




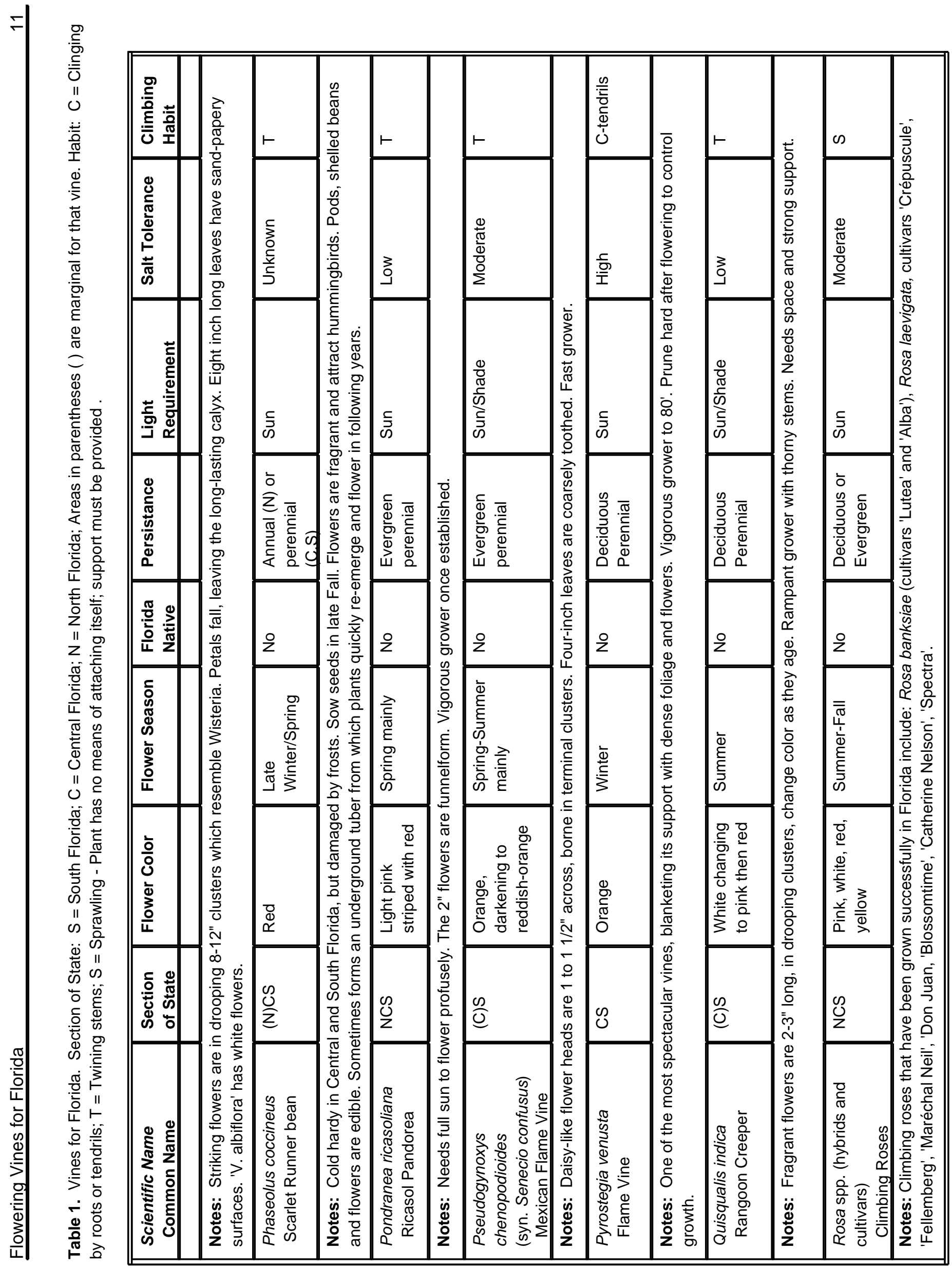


\begin{tabular}{l} 
음 \\
.5 \\
\hline 0
\end{tabular}

뭉

$\stackrel{\oplus}{5}$

$\stackrel{\square}{ \pm}$

혼

든

है

$\stackrel{0}{\frac{0}{2}}$

$=$

$\stackrel{\Phi}{\leftrightarrows}$

ปั

등

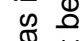

这

要

흔 응

등

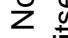

$z$.

要

은 홍

뜬 क

류ํ

II 웅

iิ

증 둔

은 空

단

이을

)

$\ddot{~ क े ~}$

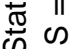

ठै

ธ

용

舲

舟

은

흔 흔

\& 등

$\stackrel{9}{\circ}$

ธั 응

은 음

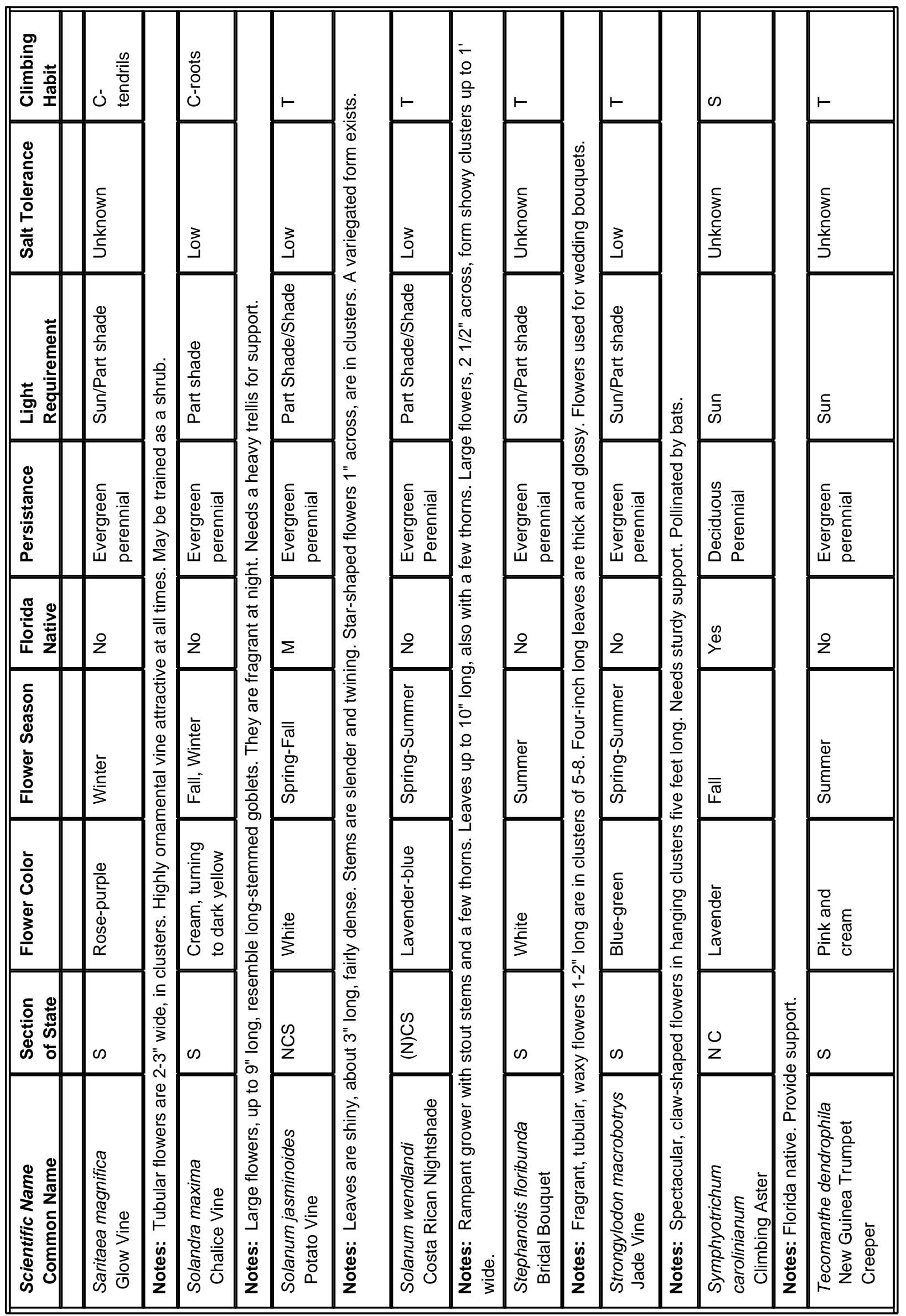




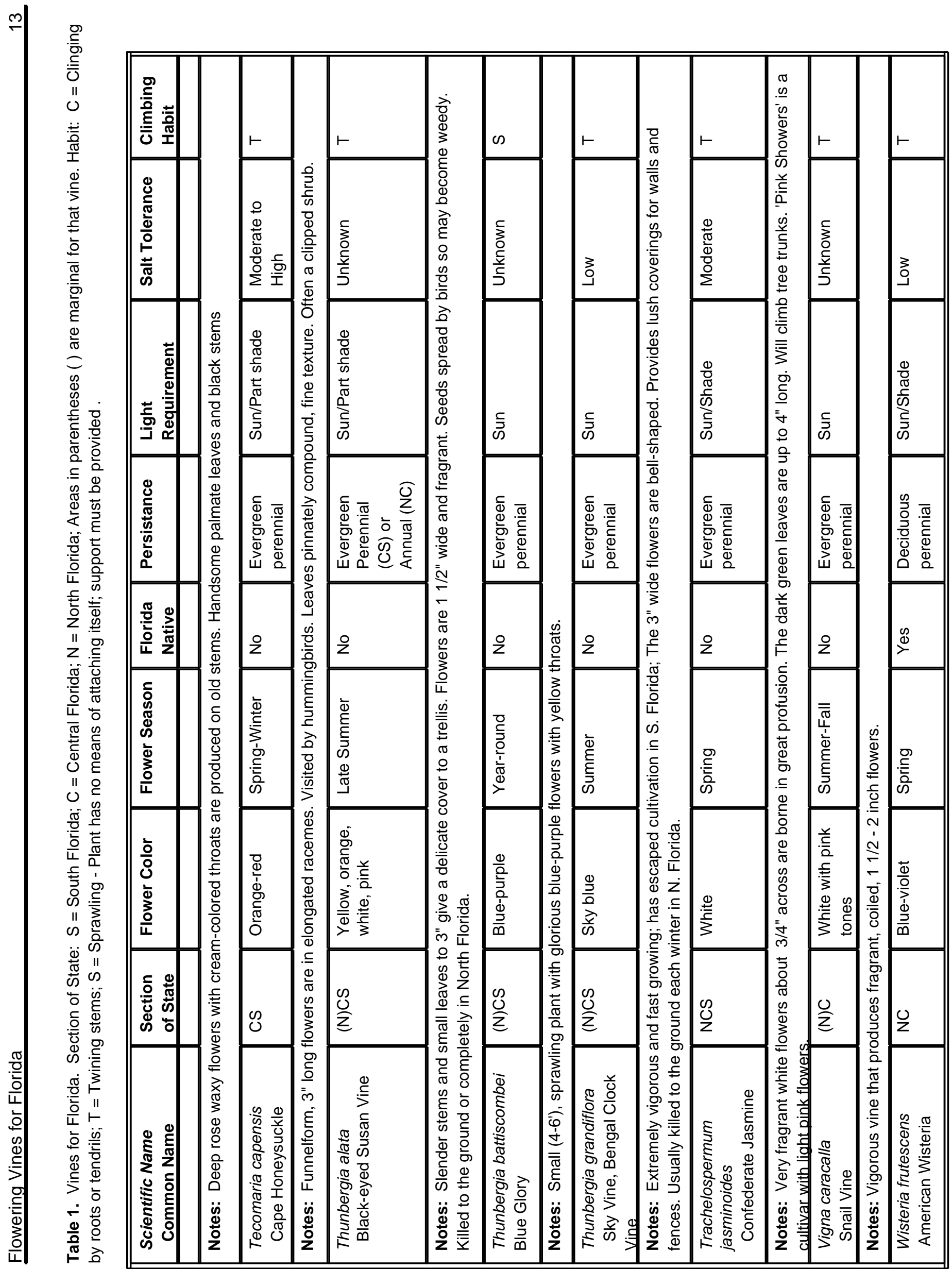


Archival copy: for current recommendations see http://edis.ifas.ufl.edu or your local extension office.

밈ำ 
Table 2. Evergreen Vines Grown for Foliage

\begin{tabular}{||l|l|l|l|l||}
\hline \hline $\begin{array}{l}\text { Cissus species } \\
\text { Grape Ivy }\end{array}$ & Shade & W & C. incisa is salt tolerant. \\
\hline Epipremum pinnatum & CS & Shade & $\mathrm{C}$ & $\begin{array}{l}\text { Not to be confused with } \mathrm{E} . \\
\text { aureum which is invasive }\end{array}$ \\
\hline $\begin{array}{l}\text { Fatshedera lizei } \\
\text { Bush Ivy }\end{array}$ & $\mathrm{NCS}$ & Shade & $\mathrm{T}$ & Variegated form available \\
\hline $\begin{array}{l}\text { Ficus pumila } \\
\text { Climbing Vine }\end{array}$ & $\mathrm{NCS}$ & $\begin{array}{l}\text { Sun/Part } \\
\text { Shade }\end{array}$ & $\mathrm{C}$ & $\begin{array}{l}\text { Vigorous vine; requires annual } \\
\text { trimming once established }\end{array}$ \\
\hline $\begin{array}{l}\text { Hedera canariensis } \\
\text { Algerian Ivy }\end{array}$ & $\mathrm{N}$ & Shade & $\mathrm{C}$ & $\begin{array}{l}\text { Large leaves up to } 6 \text { inches; } \\
\text { often used as a ground cover. }\end{array}$ \\
\hline $\begin{array}{l}\text { Hedera helix } \\
\text { English Ivy }\end{array}$ & $\mathrm{N}$ & Shade & $\mathrm{C}$ & $\begin{array}{l}\text { Many cultivars available with } \\
\text { different sizes and shapes }\end{array}$ \\
\hline $\begin{array}{l}\text { Monstera spp. } \\
\text { Philodendron species } \\
\text { and hybrids }\end{array}$ & (C)S & Shade & $\mathrm{C}$ & $\begin{array}{l}\text { Ripe fruit can be eaten fresh or } \\
\text { used in jams and jellies }\end{array}$ \\
\hline \hline
\end{tabular}

Table 3. Flowering Vines Commonly Grown as Annuals

\begin{tabular}{|c|c|c|c|}
\hline $\begin{array}{c}\text { Clitoria ternata } \\
\text { Butterfly Pea }\end{array}$ & NCS & Warm-season & $\begin{array}{l}\text { May perform as a perennial in central and south } \\
\text { Florida - See Table } 1 . \text { Re-seeds }\end{array}$ \\
\hline $\begin{array}{l}\text { Dolichos lablab } \\
\text { Hvacinth Bean }\end{array}$ & NCS & Warm-season & $\begin{array}{l}\text { Show purple flowers and seeds. Often performs as } \\
\text { a_perennial in north Florida_ See Table } 1\end{array}$ \\
\hline $\begin{array}{l}\text { Ipomoea calonyction } \\
\text { Moon Flower }\end{array}$ & NCS & Warm-season & $\begin{array}{l}\text { White flowers open at night; fragrant. Native. } \\
\text { Re-seeds }\end{array}$ \\
\hline $\begin{array}{l}\text { Ipomoea pupurea and I. } \\
\text { tricolor and hybrids } \\
\text { Morning Glories }\end{array}$ & NCS & Warm -season & $\begin{array}{l}\text { Flowers open in morning; fade late-afternoon. } \\
\text { Pinks, blues, whites. }\end{array}$ \\
\hline $\begin{array}{l}\text { Ipomoea quamoclit } \\
\text { Cypress Vine }\end{array}$ & NCS & Warm-season & $\begin{array}{l}\text { Delicate foliage; red flowers attract hummingbirds } \\
\text { and butterflies. Re-seeds aggressively. }\end{array}$ \\
\hline $\begin{array}{l}\text { Ipomoea } \times \text { sloteri } \\
\text { Cardinal Climber }\end{array}$ & NCS & Warm-season & $\begin{array}{l}\text { Hybrid of } I \text {. quamolit and } I . \text { coccinea; hummingbird } \\
\text { and butterfly attractor }\end{array}$ \\
\hline $\begin{array}{l}\text { Lophospermum erubescens } \\
\text { Creeping Gloxinia, Climbing } \\
\text { Snapdragon }\end{array}$ & NCS & Cool-season & $\begin{array}{l}\text { Red-purple, pink and white. Grows to 8'. Sun. } \\
\text { 'Wine Red' is an improved cultivar }\end{array}$ \\
\hline $\begin{array}{l}\text { Mina lobata } \\
\text { Spanish Flag/ } \\
\text { Firecracker Vine }\end{array}$ & $\mathrm{N}, \mathrm{C}$ & Warm-season & $\begin{array}{l}\text { Medium sized, twining vine to } 10-20 \text { '. Sun to } \\
\text { partial shade. Red-orange flowers summer to fall. }\end{array}$ \\
\hline $\begin{array}{l}\text { Rhodochiton atrosanguineum } \\
\text { Purple Bell Vine }\end{array}$ & NCS & Cool-season & Purple-black flowera with rose-pink calyces. \\
\hline $\begin{array}{l}\text { Phaseolus coccineus } \\
\text { Scarlet Runner Bean }\end{array}$ & NCS & Warm-season & $\begin{array}{l}\text { Often performs as a perennial in Central and South } \\
\text { Florida: edible bean; see Table } 1 .\end{array}$ \\
\hline
\end{tabular}


Table 3. Flowering Vines Commonly Grown as Annuals

\begin{tabular}{||l|l|l|l||}
\hline \hline $\begin{array}{l}\text { Thunbergia alata } \\
\text { Black-eyed Susan Vine }\end{array}$ & NCS & Warm-season & $\begin{array}{l}\text { May grow as a perennial in Central and South FL. } \\
\text { Yellow, orange, white, pink cultivars; see Table 1. }\end{array}$ \\
\hline $\begin{array}{l}\text { Tropaeolum majus } \\
\text { Nasturtiums }\end{array}$ & NCS & Cool-season & $\begin{array}{l}\text { Select vining cultivars; edible flowers and foliage } \\
\text { with peppery flavor. Orange, red, and yellow } \\
\text { flowers }\end{array}$ \\
\hline \hline
\end{tabular}

